\title{
The Effect of Brand Image on Loyalty through General Patient Satisfaction as an Intervening Variable in Makassar City Hospital
}

\author{
Mene Paradilla $^{1}$, Nurfitriani ${ }^{1}$, Siska Awawiriam ${ }^{1}$ \\ Corresponding Email: meneparadilla@gmail.com \\ ${ }^{1}$ Hospital Administration Study Program, Faculty of Health Sciences, Cokroaminoto \\ University Makassar, Indonesia
}

Received: December 25, 2021

Received in Revised: January 21, 2022

Accepted: January 31, 2022

\begin{abstract}
Loyalty is a critical component of success in today's corporate environment. Loyal clients might indirectly aid in the promotion of services to individuals in their immediate vicinity. The purpose of this research is to examine the influence of brand image on general patient loyalty at Makassar City Hospital. This is a quantitative study that combines an observational design with a cross sectional study design. The sample for this research consisted of 187 nurses working in the Makassar City Hospital's outpatient department. The findings indicated that although brand image had a direct influence on patient loyalty, it had no effect on satisfactionbased loyalty. It is recommended that hospital management develop various marketing strategies to promote the hospital's existing health services, pay close attention to patient wait times because the average patient complains about doctors who are frequently late, and pay close attention to various brands or health services such as superior products. As a result, it has become a point of differentiation for the health services supplied by other institutions.
\end{abstract}

Keywords: Brand Image, Satisfaction, Patient Loyalty, Hospital

\section{Introduction}

Loyalty is a critical component of success in today's corporate environment. Loyal clients might indirectly aid in the promotion of services to individuals in their immediate vicinity. Faithful clients are often hesitant to change locations; in other words, someone who is loyal to a product will remain loyal to it even if the price increases. In the hospital industry, customer loyalty is shown by the customer's willingness to return to the same hospital for treatment if he or his family becomes ill. Customer Loyalty is shown by consistent purchasing behavior over an extended period of time as a result of a sequence of consumer choices (Rinaldi, 2018).

The high competition among hospitals makes companies compete to increase patient loyalty so they don't move to other hospitals. Intense competition will indirectly affect a hospital in maintaining market share, hospitals must work hard in maintaining patient loyalty. For this reason, efforts to maintain patient loyalty are important things that must always be done by hospitals. Retaining consumers is an important thing that must always be done by the hospital. Patient loyalty or loyalty is based on patient satisfaction and behavior. Patient loyalty to a hospital is one of the things that becomes a measure of the success of a process of providing health services. Loyal consumers will bring other consumers to use the same product (Kotler, 2019).

Image is a set of beliefs, ideas, and impressions held by a person about an object, influenced by many factors that occur outside the company's control (Abdullah, 2015). Image is a representation of the assessment of consumers, both potential consumers and disappointed 
consumers, including other groups related to companies such as investors, agents and investors. This assessment varies, both between groups and between individuals (Jaspar, 2015).

Every patient wants good health care because health care is one of the needs of everyone. Quality if the service offered to customers is in accordance with what is desired, it will provide satisfaction. At this time, users of health services, especially those who use quality public services, do not want to see the end result in the form of healing, but they also assess what they see and feel during treatment (Indah, 2008).

Based on problem data, the number of visits to the Makassar City Hospital has decreased in the last three years, namely 2017-2019. The decrease in the number of visits was due to several factors, namely loyalty, brand image, marketing mix, satisfaction, brand equity, service quality, patient experience and referral system. The decrease in the number of old and new patient visits indicates that the interest in patient visits to return to hospital services will also decrease. This illustrates that the patient's decision to use outpatient services at RSSM Makassar is still low. Outpatient utilization that has not been optimal by the community has resulted in outpatient utilization not in accordance with management expectations which has an impact on patient loyalty to return to the hospital for treatment if they / their family are sick.

Therefore, the researcher hopes to be able to carry out further analysis on the influence of brand image through satisfaction on patient loyalty in Makassar City Hospital.

\section{Methods}

This study was place in the Makassar City Hospital. The research is quantitative in nature and employs an observational study design with a cross sectional methodology. The population of this research included all patients who received services and were admitted to the Outpatient Installation, a total of 6530 individuals. The sample size for this research was 187 respondents utilizing proportional sampling. The data collecting tool is a questionnaire, with the independent variable being brand image as determined by the choice, and the dependent variable being patient loyalty.

Univariate analysis was utilized to get an overview of the research topic by detailing each variable employed in the study and the respondents' characteristics. The univariate analysis included a descriptive examination of respondents' characteristics, a descriptive examination of research factors, and a crosstabulation examination of respondents' characteristics and research variables. The bivariate analysis was used to determine the connection between two variables, namely the independent and dependent variables. The Chi Square test was utilized as the statistical test. Analyses of many individuals with path analysis (path analysis).

\section{Results and Discussion}

Table 1. Characteristics of Makassar City Hospital Patients in 2022

\begin{tabular}{|c|c|c|c|c|c|}
\hline \multirow{2}{*}{ No. } & \multirow{2}{*}{ Characteristics of Respondents } & $\begin{array}{c}\text { Number } \\
(\mathbf{n})\end{array}$ & $\begin{array}{c}\text { Percentage } \\
(\boldsymbol{\%})\end{array}$ & \multirow{2}{*}{ Total } \\
\hline \multirow{3}{*}{1.} & \multirow{2}{*}{ Gender } & Man & 41 & 21.9 & \\
\cline { 3 - 4 } & & Woman & 146 & 78.1 & \multirow{2}{*}{187} \\
\cline { 3 - 5 } & & $15-19$ & 9 & 4.8 & \\
\cline { 3 - 5 } & & $20-24$ & 20 & 10.7 \\
\cline { 3 - 5 } & & $25-29$ & 18 & 9.6 \\
\cline { 3 - 5 } & & $30-34$ & 22 & 11.8 \\
\hline
\end{tabular}

Copyright (O) 2022, Journal of Asian Multicultural Research for Medical and Health Science Study, Under the license CC BY-SA 4.0 


\begin{tabular}{|c|c|c|c|c|c|}
\hline \multirow{6}{*}{2.} & \multirow{6}{*}{ Age } & $35-39$ & 18 & 9.6 & \multirow{6}{*}{187} \\
\hline & & $40-44$ & 25 & 13.4 & \\
\hline & & $45-49$ & 15 & 8.0 & \\
\hline & & $50-59$ & 15 & 8.0 & \\
\hline & & $60-64$ & 13 & 7.0 & \\
\hline & & $>65$ & 32 & 17.1 & \\
\hline \multirow{7}{*}{3.} & \multirow{7}{*}{ The Last Education } & $\begin{array}{c}\text { Elementary } \\
\text { School }\end{array}$ & - & - & \multirow{7}{*}{187} \\
\hline & & Junior School & - & - & \\
\hline & & High School & 9 & 4.8 & \\
\hline & & Diploma & 49 & 26.2 & \\
\hline & & Bachelor & 98 & 52.4 & \\
\hline & & Master & 31 & 16.6 & \\
\hline & & Other & - & - & \\
\hline \multirow{7}{*}{4.} & \multirow{7}{*}{ Work } & Student & - & - & \multirow{7}{*}{187} \\
\hline & & Student & 9 & 4.8 & \\
\hline & & $\begin{array}{c}\text { Self } \\
\text { employed }\end{array}$ & 26 & 13.9 & \\
\hline & & $\begin{array}{c}\text { Private } \\
\text { Employees }\end{array}$ & 31 & 16.6 & \\
\hline & & Civil Servants & - & - & \\
\hline & & Not Working & 34 & 18.2 & \\
\hline & & Other & 87 & 46.5 & \\
\hline \multirow{4}{*}{5.} & \multirow{4}{*}{ Care Classes } & Class I & 19 & 10.2 & \multirow{4}{*}{187} \\
\hline & & Class 2 & 56 & 29.9 & \\
\hline & & Class 3 & 47 & 25.1 & \\
\hline & & VIP & 65 & 34.8 & \\
\hline \multirow{2}{*}{6.} & \multirow{2}{*}{ Distance to hospital } & $<5 \mathrm{KM}$ & 40 & 21.4 & \multirow{2}{*}{187} \\
\hline & & $>5 \mathrm{KM}$ & 147 & 78.6 & \\
\hline \multirow{2}{*}{7.} & \multirow{2}{*}{ Number of visits } & $>1$ times & 36 & 19.3 & \multirow{2}{*}{187} \\
\hline & & Infinite & 151 & 80.7 & \\
\hline
\end{tabular}

\section{Source: Primary Data}

The frequency distribution in Table 1 is based on the sample's characteristics at the study site, with the majority of respondents at Makassar City Hospital being female, namely 146 persons (78.9 percent) with an age $>65$ and as much as 32 people (17.1 percent ). The most recent schooling received by as many as 98 persons was S1 (52.4 percent ). Entrepreneurship is the most common profession, accounting for up to 87 persons (46.5 percent ). As many as 65 individuals may be accommodated in a VIP treatment class (34.8 percent ). The number of persons who live more than 5 kilometers from a hospital is 147 (78.9 percent), and the number of visits is limitless, namely 151. (80.7 percent). 
Table 2. Makassar City Hospital Research Variables in 2022

\begin{tabular}{|c|c|c|}
\hline Brand Image & Sum & \% \\
\hline Good & 116 & 62.0 \\
\hline Bad & 71 & 38.0 \\
\hline Total & $\mathbf{1 8 7}$ & $\mathbf{1 0 0 . 0}$ \\
\hline Satisfaction & Sum & \% \\
\hline Good & 115 & 61.5 \\
\hline Bad & 72 & 38.5 \\
\hline Total & $\mathbf{1 8 7}$ & $\mathbf{1 0 0 . 0}$ \\
\hline Satisfaction & Sum & \% \\
\hline Good & 116 & 62.0 \\
\hline Bad & 71 & 38.0 \\
\hline Total & $\mathbf{1 8 7}$ & $\mathbf{1 0 0 . 0}$ \\
\hline
\end{tabular}

Source: Primary Data

Table 2 summarizes respondents' ratings of the study factors as a percentage. The majority of respondents (62.0 percent) said that they had a favorable brand image, 69.5 percent indicated that they had a high level of satisfaction, and 62.0 percent indicated that they had a high level of loyalty. The link between the independent and dependent variables is shown in Table 3.

Table 3. Influence of Research Variables of Makassar City Hospital in 2022,

Influence between Brand Image on Loyalty in Makassar City Hospital in 2021

\begin{tabular}{|c|c|c|c|c|c|c|c|}
\hline \multirow{3}{*}{ Brand Image } & \multicolumn{4}{|c|}{ Loyalty } & \multirow{2}{*}{\multicolumn{2}{|c|}{ Total }} & \multirow{3}{*}{$\begin{array}{c}p- \\
\text { value }\end{array}$} \\
\hline & \multicolumn{2}{|c|}{ Good } & \multicolumn{2}{|c|}{ Bad } & & & \\
\hline & $\mathbf{N}$ & $\%$ & $\mathbf{N}$ & $\%$ & n & $\%$ & \\
\hline Good & 103 & 88.8 & 13 & 11.2 & 116 & 100,0 & \\
\hline $\mathrm{Bad}$ & 13 & 18.3 & 58 & 81,7 & 71 & 100,0 & 0,001 \\
\hline Total & 116 & 62.0 & 71 & 38.0 & 187 & 100,0 & \\
\hline
\end{tabular}

Source: Primary Data, 2022

The analysis's findings indicate that the variables brand image, marketing mix, and satisfaction all have an influence on loyalty at the Makassar City Hospital's Outpatient Installation. The bivariate analysis revealed that brand image had a significant impact on loyalty with a $\mathrm{p}$ value $=0.0010 .05$, satisfaction had a significant influence on loyalty with a $p$ value $=0.0010 .05$, and satisfaction had a significant influence on loyalty with a $\mathrm{p}$ value $=0.0010 .05$. The route analysis between variables based on the hypothesis is shown in Table 4.

Table 4. This analysis of researchers wanted to see the influence of variable dimensions on their variables on hospital installations. The statistical test used is CFA.

CFA Brand Image

\begin{tabular}{|l|l|l|l|l|l|l|}
\hline & Estimate & Std.Err & z-value & $\mathrm{P}(>|\mathrm{z}|)$ & Std.lv & Std.all \\
\hline \multicolumn{7}{|l|}{ Brand = } \\
\hline AA & 1.000 & & & & 3.447 & 0.920 \\
\hline AB & 1.973 & 0.091 & 21.671 & 0.000 & 6.802 & 0.972 \\
\hline AC & 0.621 & 0.043 & 14.479 & 0.000 & 2.142 & 0.776 \\
\hline
\end{tabular}

CFA Satisfaction

Copyright $@$ (2022, Journal of Asian Multicultural Research for Medical and Health Science Study, Under the license CC BY-SA 4.0 


\begin{tabular}{|l|l|l|l|l|l|l|}
\hline & Estimate & Std.Err & z-value & $\mathrm{P}(>|\mathrm{z}|)$ & Std.lv & Std.all \\
\hline \multicolumn{7}{|l|}{ Satisfaction $=\sim$} \\
\hline CA & 1.000 & & & & 10.283 & 0.993 \\
\hline CB & 0.235 & 0.011 & 21.307 & 0.000 & 2.416 & 0.851 \\
\hline CC & 0.241 & 0.006 & 40.149 & 0.000 & 2.480 & 0.960 \\
\hline CD & 0.089 & 0.004 & 20.995 & 0.000 & 0.918 & 0.847 \\
\hline
\end{tabular}

CFA Loyalty

\begin{tabular}{|l|r|l|l|l|l|l|}
\hline & Estimate & Std.Err & z-value & $\mathrm{P}(>|\mathrm{z}|)$ & Std.lv & Std.all \\
\hline & & & & & & \\
\hline \multicolumn{7}{|l|}{ Loyalty $=\sim$} \\
\hline DA & 1.000 & & & & 1.545 & 0.875 \\
\hline DB & 0.971 & 0.074 & 13.186 & 0.000 & 1.499 & 0.779 \\
\hline DC & 1.087 & 0.073 & 14.913 & 0.000 & 1.679 & 0.838 \\
\hline DD & 1.610 & 0.093 & 17.246 & 0.000 & 2.486 & 0.915 \\
\hline
\end{tabular}

The influence of brand image on satisfaction is determined by the fact that the $\mathrm{P}$ value for the Brand Image variable is less than 0.05, indicating that Brand Image has a direct and positive effect on patient loyalty of 0.339 (33.9 percent). According to Substructure I, every improvement in Brand Image has a direct influence on enhancing patient loyalty by as much as 0.339 . (33.9 percent ). R21 (coefficient of determination) is 0.947 . This suggests that although Satisfaction accounts for 94.7 percent of the variance in loyalty, the remaining 5.3 percent is explained by other factors. While the $\mathrm{P}$ value for the Brand Image variable, 0.030, is less than 0.05, this indicates that Brand Image has a direct and positive influence on satisfaction of 0.234 (23.4 percent). Thus, every improvement in Brand Image has a direct influence on boosting satisfaction by up to 0.234 . (23.4 percent ). R21 (coefficient of determination) equals 0.945. This suggests that the Brand variable accounts for 94.5 percent of the variance in satisfaction, while the remaining 5.5 percent is explained by other factors. The route analysis between variables based on the hypothesis is shown in Table 5 .

Table 5. The Direct Influence of Brand Image on Loyalty

\begin{tabular}{|l|l|l|l|l|}
\hline Influence of Langsung & Estimate & Std. Dev & T Statistics & P Values \\
\hline Satisfaction -> Loyalitas_Pasien & 0.735 & 0.092 & 7.960 & $\mathbf{0 . 0 0 0}$ \\
\hline Brand_-> Loyalitas_Pasien & 0.339 & 0.099 & 3.436 & $\mathbf{0 . 0 0 1}$ \\
\hline Brand_-> Satisfaction & 0.234 & 0.107 & 2.177 & $\mathbf{0 . 0 3 0}$ \\
\hline
\end{tabular}

\begin{tabular}{|l|l|}
\hline R-Square & Estimate \\
\hline Loyalty & 0.947 \\
\hline Satisfaction & 0.945 \\
\hline
\end{tabular}

The influence of brand image on satisfaction is shown by the fact that the $\mathrm{P}$ value for the Brand Image variable, 0.033, is less than 0.05, indicating that Brand Image has an indirect and positive effect on patient loyalty of $0.172(17.2 \%)$ through satisfaction. As a result, it may be stated that every improvement in Brand Image has an indirect influence on patient loyalty of up to 0.172 via satisfaction (17.2 percent ). The following equation may be used to compute the size of the coefficient of determination in general: $\mathrm{M}=0.997-(1-\mathrm{R} 21)(1-\mathrm{R} 22)$ 
This suggests that $99.7 \%$ of patient loyalty can be described directly or indirectly by the Marketing Mix and Brand Image, whereas the remaining 0.3 percent may be explained by additional factors not included in the model.

The research hypothesis 1 (H1) is presented clearly in terms of the effect of brand image on patient satisfaction in an outpatient setting. According to the statistical research undertaken, it is known that brand image has an effect on patient satisfaction at the Makassar City Hospital's Outpatient Installation. A significance score of 0.000 also indicates a substantial impact, indicating that study hypothesis 1 (H1) is adopted in this circumstance.

The brand image alluded to in this research refers to the hospital's actions in developing the name and qualities of a product, as well as tariffs and services, which are distributed through different channels in order for customers to recall the brand. The researchers aim to know how patients perceive the performance of brand image measurement at the Makassar City Hospital's Outpatient Installation using the indicators of Corporate Identity, Physical Environment, and Service Offering.

Overall, the study's findings indicate that $62 \%$ of respondents have a favorable view of a brand, are female, between the ages of 40 and 44, have a bachelor's degree, and operate as entrepreneurs with VIP treatment courses located away from hospitals. an average distance of $>5$ kilometers, and the number of visits is limitless.

According to Kotler (2019), satisfaction is a sense of joy or disappointment that customers experience when their perceptions of a product's or service's outcomes or performance are compared to their expectations. If the customer's impression of the product or service is consistent with the consumer's expectations, the consumer is content; nevertheless, if the consumer's perspective falls short of the consumer's expectations, the consumer is unsatisfied or disappointed.

Overall, the study's findings reveal that 61.5 percent of respondents have a favorable sense of satisfaction, are female, between the ages of 25 and 29, have a bachelor's degree as their most recent education, and work as entrepreneurs with class 3 care, a distance from home. The typical hospital is almost 5 kilometers away, and the number of trips is limitless.

Research result (Sciulli \& Missien, 2015) states that overall satisfaction affects customer loyalty which implies that marketers should focus on the benefits of brand image to achieve customer loyalty.

The second research hypothesis $(\mathrm{H} 2)$ indicated that brand image has an effect on patient loyalty in the outpatient setting. According to the statistical research undertaken, it is known that brand image has an effect on patient loyalty at the Makassar City Hospital's Outpatient Installation. A significance value of 0.001 also indicates a substantial impact, indicating that study hypothesis $2(\mathrm{H} 2)$ is adopted in this circumstance.

The brand image alluded to in this research refers to the hospital's actions in developing the name and qualities of a product, tariff, or service, which are then disseminated in different media in order for customers to remember the brand. The researchers are interested in the patient's opinion of the installation's performance in terms of brand image measurement.

Overall, the study's findings indicate that $62 \%$ of respondents have a favorable view of a brand, are female, between the ages of 40 and 44, have a bachelor's degree, and operate as entrepreneurs with VIP treatment courses located away from hospitals. an average distance of $>5$ kilometers, and the number of visits is limitless. This is possible because brand image is not 
the sole factor affecting patient loyalty. Along with the brand image being investigated at the moment, there are other aspects that might influence patient loyalty.

Patient loyalty is defined in this study as the development of a consumer's attitudes and behavioral patterns toward purchasing and using products based on previous experiences, utilizing other hospital services, recommending the hospital to family and friends, and remaining unaffected by the attractiveness of competitors, as measured by the reprat indicators purchase, play more, retention, and advocate.

Overall, the study's findings indicate that $62 \%$ of respondents have a favorable opinion of loyalty, are female, between the ages of 40 and 44, have a bachelor's degree as their most recent education, and work as entrepreneurs in areas with a Class 3 treatment class and a distance from a hospital. an average distance of $>5$ kilometers, and the number of visits is limitless.

According to the results of the research conducted at Makassar City Hospital, 18.7 percent of patients expressed extreme dissatisfaction with the statement "The financing for the services I received was relatively affordable," and as many as 28.3 percent expressed dissatisfaction with the statement "I feel proud when using the services of this hospital."

The corporate visual identity is used to express the presence of a firm, organization, institution, or group via the use of names, symbols, typography, colors, and slogans (taglines/slogans).

5 However, before developing a corporate visual identity (corporate visual identity), a designer must comprehend the intricacies of the message the business want to express. By comprehending the message that the firm want to express, it will be able to easily reach the intended audience through the company's visual identity (corporate visual identity) that is applied.

Numerous aspects are required to create a company visual identity, including a logo, color, typography, shape, line, and picture. By mixing these features, it is possible to create a company's visual identity.

According to the results of the research conducted at Makassar City Hospital, 18.7 percent of patients expressed extreme dissatisfaction with the statement "Toilet and canteen conditions" and as many as 25.1 percent expressed dissatisfaction with the statement "Parking facilities (parking area) are adequate."

According to Kotler (1996), a service is "any act or performance that a party may provide to another that is fundamentally intangible and does not result in ownership of anything; its creation may or may not result in the production of a physical commodity." The argument is that service is any action or activity that one party may provide to another that is mostly intangible and does not result in the transfer of property. Its manufacture may or may not be associated with a specific physical product.

Service quality is one of the key indicators of a government's performance in conducting its functions. The greater the quality, the more satisfied the public is with service institutions (Anggasta, 2005).

The results of the research at the Makassar City Hospital showed that 187 respondents found that $12.8 \%$ of patients stated that they were very dissatisfied with the statement "Doctors are always on time" and $29.9 \%$ said they were not satisfied with the statement "When they come for treatment, the administrative officer is always there".

Research result (Hayuningtyas, 2020) shows that the company's brand image has a significant effect on customer commitment and loyalty. Therefore, companies need to specifically focus

Copyright $@$ 2022, Journal of Asian Multicultural Research for Medical and Health Science Study, Under the license CC BY-SA 4.0 
on long-term and mutually beneficial profitability relationships with customers and create loyalty as a competitive advantage in the market.

Research hypothesis 3 (H3) stated satisfaction with patient loyalty in the Outpatient Installation. Based on the statistical analysis conducted, it is known that satisfaction with patient loyalty in the Outpatient Installation at the Makassar City Hospital. A significant effect is also shown by a significance value of 0.001 so that in this case research hypothesis $3(\mathrm{H} 3)$ is accepted.

Research result Abdullaeva, (2020) shows that there is a significant relationship between satisfaction and loyalty. In line with research Fatima et al (2018) shows that there is a significant and positive effect between patient satisfaction and loyalty from six private hospitals in the capital, Islamabad, Pakistan.

The hypothesis in this study is to see how the indirect effect of brand image on loyalty through general patient satisfaction at Stella Maris Hospital Makassar. Based on the results of the statistical test the $\mathrm{P}$ value on the Total variable, 0.000 is smaller than 0.05 , so it can be concluded that the brand image variable has a direct and indirect effect on patient loyalty through satisfaction.

\section{Conclusion}

The study's findings indicate that brand image has both a direct and indirect influence on loyalty through satisfaction. Hospital management should analyze the brand image in order to directly boost patient happiness at the hospital. This evaluation should take into account numerous brand image indicators, including the cooperative identity, physical environment, and service provision. Because on the research's findings, the brand's image is not favorable and 60 respondents are dissatisfied with it (84.5 percent). Hospital administration monitors brand image in order to improve patient loyalty directly via numerous brand image indicators, including cooperative identity, physical environment, and service providing. As a consequence of the study findings, brand image is poor and loyalty is low among 58 respondents $(81.7$ percent). Facility administration should measure patient satisfaction to ensure that pleased patients return to the hospital. The study's findings on the degree of satisfaction of patients with poor loyalty included 57 respondents (79.2 percent). Hospital administration should consider the indirect impact of brand image on patient loyalty through satisfaction. The study found that brand image had a direct effect on loyalty of 0.085 and an indirect effect of $0.085+0.788$ of 0.873 through satisfaction as an intervening variable. The indirect impact is more valuable than the direct effect, which indicates that the patient must first be happy with the services supplied before becoming loyal. Hospital management should assess marketing's indirect influence on patient loyalty through satisfaction. According to the study's findings, marketing mix has a direct influence on loyalty of 0.108 and an indirect effect on loyalty through satisfaction as an intervening variable of $0.503+0.788$ of 1.291 . The indirect impact is more valuable than the direct effect, which indicates that the patient must first be happy with the services supplied before becoming loyal.

\section{References}

Abdullaeva, M. (2020). Impact of Customer Satisfaction on Customer Loyalty in Upscale Ethnic Restaurants. Theoretical \& Applied Science, 86(06), 372-375.

Abdullah, A. (2015). A Structural Model of The Relationships between Brand Image, Brand Trust and Brand Loyalty. International Journal of Management Research \& Review, 5(3), 137-145. 
Anggasta, G. (2005). Analisis Dimensi Kualitas Pelayanan Rumah Sakit Umum Daerah Kabupaten Batang. Ilmu Administrasi Publik, 3.

Fatima, T., Malik, S. A., \& Shabbir, A. (2018). Hospital healthcare service quality, patient satisfaction and loyalty: An investigation in context of private healthcare systems. International Journal of Quality and Reliability Management, 35(6), 1195-1214.

Hayuningtyas, P. (2020). the Impact of Marketing Mix on Cunsomer Satisfaction and. 4(June 2015), 83-103.

Indah Z. A. S, H. A. (2008). Pengaruh Kualitas Pelayanan Terhadap Loyalitas Pasien Umum Rsud Sungai Dareh Dengan Kepuasaan Pasien Sebagai Variabel Intervening. Manajemen Pemasaran, 49(1), 11.

Jaspar. (2015). Analisis Hubungan Bauran Pemasaran Terhadap Loyalitas Pasien Di Unit Pelayanan Rawat Jalan Rumah Sakit Kartini Tahun 2018. Jurnal Manajemen Rumah Sakit, 2(2), 1-24.

Kotler. (2019). Marketing in higher education: promoting educational services and programmes. May.

Rinaldi, E. A. (2018). Analisis hubungan bauran pemasaran terhadap loyalitas pasien di unit pelayanan rawat jalan Rumah Sakit Kartini Tahun 2018. Jurnal Bidang Ilmu Kesehatan, 12(2), 1-14.

Sciulli, L. M., \& Missien, T. L. (2015). Hospital service-line positioning and brand image: influences on service quality, patient satisfaction, and desired performance. Innovative Marketing, 11(2), 20-29. 